\title{
Konseling Gestalt Berbasis Islam dalam Upaya Meningkatkan Kemampuan Regulasi Diri Santri di Pondok Pesantren Al-Falaah Pandak Bantul Yogyakarta
}

\section{Nurviyanti Cholid}

STAIN Syaikh Abdurrahman Siddik Bangka Belitung, Indonesia vivihafizh@gmail.com

\begin{abstract}
This research was motivated by there is an opportunity for the use of Islamic scholarship concepts that serve as material in Islamic guidance and counseling services to improve self-regulation of santri. the final result proposed in this study is guidance and counseling Gestalt-based Islam can improve selfregulation of santri. The purpose of this study is to determine the role of guidance and counseling Gestaltbased Islam to improve the regulation of boarding school boarding school Al-Falaah Pandak Bantul Yogyakarta. This type of research is a qualitative description research. The population of this study is all students aged 13-14 years. The sample in this research is determined by random assigment technique from population. The sample in this research is determined by random assigment technique from population. The total number of samples in this study were 24 santri given intervention in the form of guidance and counseling Gestalt Islam based Data collected by questionnaire, observation and interview. Gestalt counseling on the basis of Islam is quite effective in improving the self-regulating ability of the students at the boarding school Al-Falaah Pandak Bantul Yogyakarta. Therefore, the findings of the research results can be used as a reference in developing Islamic counseling and counseling to develop the potential of an individual.
\end{abstract}

Keywords; Guidance and counseling, Gestalt Approach, Self Regulation

Received: 04-10-2017; accepted: 14-11-2017; published: 02-12-2017 


\section{A. Pendahuluan}

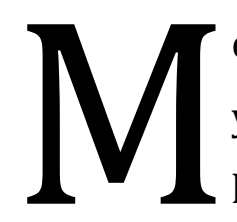

enurut pendapat Federick Perls ${ }^{1}$ terapi Gestalt adalah bentuk terapi eksistensial yang berpijak pada premis bahwa individu-individu harus menemukan jalan hidupnya sendiri dan menerima tanggung jawab pribadi jika mereka berharap mencapai kematangan. Pendapat tentang konseling dengan pendekatan Gestalt juga diungkapkan oleh Rosjidan² yang menyatakan bahwa terapi Gestalt adalah suatu bentuk terapi eksistensial-fenomenologi yang berfokus kepada usaha untuk membawa pengalaman langsung sekarang ke dalam kesadaran yang meningkat dan yang lebih besar kejelasannya.

Prinsip utama dalam teori Gestalt adalah kesadaran dan tanggung jawab. Santri yang mempunyai regulasi diri yang buruk mengindikasikan ada sesuatu permasalahan yang belum terselesaikan dalam diri santri tersebut, hingga dia tidak mampu memanfaatkan potensi secara penuh, melainkan baru memanfaatkan sebagaian dari potensi yang dimilikinya.

Rendahnya regulasi diri santri dikarenakan kurangnya tanggung jawab, motivasi dan kesadaran tentang dirinya sendiri maupun kehidupannya. Kesadaran dalam diri santri ini dapat ditumbuhkan melalui pendekatan dalam konseling Gestalt melalui beberapa tehnik dengan menggunakan nilai-nilai luhur yang ada dalam Islam. Setelah santri menyadari tentang dirinya sendiri seperti menyadari akan eksistensinya di dunia melalui tausiah-tausiah Islami, maka langkah konselor selanjutnya adalah menumbuhkan rasa tanggung jawab melalui tekhnik dalam gestalt seperti teknik berkeliling, saya bertanggung jawab atas.

\section{B. Teori Yang Dikembangkan}

\section{Saat sekarang (here and now)}

Perls mengatakan bahwa "kekuatan ada pada masa kini". Pendekatan ini mengutamakan masa sekarang, segala sesuatu tidak ada kecuali yang ada pada masa sekarang, karena masa lalu telah berlalu dan masa depan belum sampai, hanya masa sekarang yang penting. Hal ini karena dalam pendekatan Gestalt mengapresiasi pengalaman pada masa kini ${ }^{3}$. Pengalamanpengalaman beberapa menit lalu, beberapa hari, beberapa tahun, beberapa dekade yang lalu yang mempunyai kaitan makna penting dengan sekarang maka akan dibicarakan 4 .

\footnotetext{
${ }^{1}$ Gerald Corey, Teori dan Praktek Konseling dan Psikoterapi, (Bandung: PT. Eresco, 2010), p. 118.

${ }^{2}$ Rosjidan, Panduan Pengajar Pengantar Teori Konseling III, (Jakarta: Depdikbud, 1998), p. 111

${ }^{3}$ Corey, Teori dan Praktek, p. 122.

${ }^{4}$ Rosjidan, Panduan Pengajar...p. 135
} 
Dalam terapi Gestalt lebih berorientasi pada waktu sekarang. Pengalaman-pengalaman beberapa menit yang lalu, beberapa hari, beberapa tahun, beberapa dekade yang lalu yang memiliki kaitan penting dengan sekarang maka akan dibicarakan. Konselor meminta konseli agar membawa masa lalunya itu ke saat sekarang dengan menjalaninya kembali seakan-akan masa lampau itu hadir pada saat sekarang.

\section{Konfrontasi}

Konfrontasi menurut Nursalim ${ }^{5}$ adalah mengenal secara jujur dan langsung serta untuk menunjukkan pada konseli apa yang sedang terjadi atau apa yang diperkirakan sedang terjadi. Pengaruhnya adalah tantangan, pengungkapan atau ancaman. Akibat emosional biasanya konseli merasa cemas apabila konselor memberikan suatu balikan. Kadang-kadang konseli merasa senang karena konselor memberikan pendapat-pendapatnya secara jujur dengan penuh perhatian.

\section{Urusan Yang Tak Terselesaikan}

Salah satu konsep utama terapi Perls adalah "unfinished business" atau urusan yang tak terselesaikan. Yang mencangkup urusan tak terselesaikan adalah emosi-emosi, peristiwaperistiwa , ingatan-ingatan, yang terlambat dinyatakan oleh individu yang bersangkutan. Hal ini membuat hubungan individu dengan lingkungan dapat terganggu ${ }^{6}$.

Pendapat lain juga diungkapkan Rodjidan $^{7}$ mengenai urusan belum terselesaikan. Perasaan-perasaan tidak dinyatakan (seperti perasaan dosa, marah, benci, kesedihan) yang berasal dari masa kanak-kanak yang sekarang mengganggu kepada berfungsinya psikologis yang efektif.

Dari pendapat-pendapat diatas maka dapat disimpulkan bahwa urusan yang tak selesai yakni mencakup perasaan-perasaan yang tidak terungkap seperti dendam, kemarahan, kebencian, sakit hati, kecemasan, rasa berdosa, rasa diabaikan dan sebagainya. urusan yang tak selesai itu akan bertahan sampai ia menghadapi dan menangani perasaan-perasaan yang tak terungkap itu.

\section{Tujuan Konseling Gestalt}

5 Tio Yoga Sugama, “Teknik Konfrontasi dalam Konseling”, Diakses dari http://bkfkipuhamka.com/index.php?option=com/content\&view=article\&id=75; teknik-konfrontasi-dalamkonseling\&catid=45:karya-mahasiswa\&Itemid=82 pada tanggal 29 Desember 2014, pukul 21.00 WIB.

${ }^{6}$ Mohamad Surya, Dasar-dasar, p. 245.

${ }^{7}$ Rosjidan, Panduan Pengajar, p. 34. 
Laura Perls menyatakan bahwa tujuan terapi Gestalt adalah kontinum kesadaran, pembentukan Gestalt yang berlangsung dengan bebas dimana apa yang menjadi perhatian dan kepentingan terbesar pada individu. ${ }^{8}$ Pendapat senada juga dinyatakan oleh Stephen Palmer ${ }^{9}$ yang mengemukakan tujuan terapi Gestalt adalah menumbuhkan kesadaran dan metodologi primernya dalam hal kesadaran. Kesadaran tentang bagaimana seseorang berada di dunia yang membebaskan individu membuat pilihan.

Penjelasan lebih lanjut diungkapkan oleh Gerald Corey ${ }^{10}$ yang menyatakan sasaran utama terapi Gestalt adalah pencapaian kesadaran. Kesadaran yang dimaksud disini adalah kesadaran dengan dirinya sendiri. Berbeda halnya dengan Sayeti Pujosuwarno yang berpendapat bahwa tujuan konseling Gestalt adalah sebagai usaha membantu konseli dalam mengintegrasikan diri dalam lingkungannya dan membantu konseli menjadi masak dan bergerak kearah aktualisasi diri. ${ }^{11}$

Menurut Akhmad Sudrajad, tujuan utama konseling Gestalt adalah membantu konseli agar berani menghadapi berbagai macam tantangan maupun kenyataan yang harus dihadapi. 12 Berdasarkan beberapa pendapat tersebut maka peneliti lebih memilih untuk mengikuti pendapat Gerald Corey dalam tujuan konseling Gestalt. Pendapat tersebut memuat tentang tujuan konseling agar konseli memperoleh kesadaran pribadi, memahami kenyataan atau realitas, serta mendapatkan insight secara penuh. Peningkatan kesadaran diri ini bertujuan agar konseli dapat bertingkah laku menurut prinsip-prinsip Gestalt, semua situasi bermasalah yang muncul dan selalu akan muncul dapat diatasi dengan baik.

\section{Konsep Dasar Konseling Gestalt Berbasis Islam}

Di dalam sumber ajaran Islam yang terdapat pada al-Qur'an dan hadist banyak mengandung ayat-ayat konseling, hanya saja ayat-ayat tersebut tersebar di berbagai tempat dan belum tersusun secara sistematis dan dipilah-pilah seperti dalam konseling konvensional. Terutama dalam sistematika mengenai; hakikat manusia, pribadi sehat, pribadi tidak sehat, konsep konseling, peran dan fungsi konselor serta teknik dan prosedur dalam konseling. Oleh karena itu kiranya tidak terlalu berlebihan jikalau di dalam tulisan ini penulis berusaha untuk

\footnotetext{
${ }^{8}$ Ibid.

${ }^{9}$ Stephen Palmer, Konseling dan Psikoterapi (Yogyakarta: Pustaka Belajar, 2011), p. 152.

${ }^{10}$ Corey, Teori dan Praktek, p. 124.

${ }^{11}$ Sayeti Pujosuwarno, Berbagai Pendekatan, p. 74

12 Akhmad Sudrajad, Mengatasi Masalah Siswa Melalui Layanan Konseling Individual, (Yogyakarta:
} Paramitra, 2011), p. 52 
mencari bahan dari sumber Islam untuk dijadikan muatan materi dalam pemberian intervensi konseling.

Pada praktiknya, konsep-konsep yang terdapat di dalam teori konseling gestalt ini akan dikaitkan dengan pendekatan-pendekatan yang terdapat dalam Islam. Dengan berbasis pada budaya atau nilai-nilai yang terkandung di dalam Islam, maka diharapkan dapat efektif meningkatkan regulasi diri santri. Perlu dijelaskan di sini bahwa konseling berbasis agama Islam yang dimaksud adalah proses pemberian bantuan terarah, kontinu dan sistematis kepada setiap individu agar ia dapat mengembangkan potensi atau fitrah beragama yang dimilikinya secara optimal dengan cara menginternalisasikan nilai-nilai yang terkandung dalam al-Quran dan hadist ke dalam dirinya, sehingga ia dapat hidup selaras dan sesuai dengan tuntutan yang terkandung di dalamnya.

Apabila internalisasi nilai yang terkandung dalam ajaran Islam telah tercapai dan fitrah agama itu telah berkembang secara optimal maka individu tersebut dapat menciptakan hubungan yang baik dengan Allah, manusia dan alam semesta sebagai manisfestasi dari peranannya sebagai khalifah di muka bumi yang sekaligus juga berfungsi untuk mengabdi kepada Allah. Pemberian bantuan kepada individu agar memiliki kemampuan untuk mengembangkan fitrahnya sebagai makhluk beragama, berperilaku sesuai dengan nilai-nilai agama (berakhlak mulia), dan mengatasi masalah-masalah kehidupan melalui pemahaman, keyakinan, dan praktik-praktik ibadah ritual agama. ${ }^{13}$

Mengacu pada pendapat di atas, maka dapat diketahui bahwa konseling berbasis islam mengandung aspek spiritual dan material. Dimensi spiritual adalah membimbing manusia pada kehidupan rohaniah untuk menjadi beriman dan bertaqwa kepada Allah. Sedangkan dimensi material membantu manusia untuk dapat memecahkan masalah kehidupan agar dapat mencapai kebahagiaan selama hidupnya.

Dari uraian tentang konsep dasar tersebut, maka dapat disimpulkan bahwa penggunaan basis Islam pada konseling gestalt akan lebih memperkuat arah dan tujuan konseling yang lebih jelas. Karena telah diketahui bahwa individu memiliki sisi spiritual (fitrah beragama) yang perlu mendapat perhatian. Konseling konvensional saja tidak cukup untuk menuntaskan permasalahan siswa. Maka disini berbasis Islam dengan kelebihan dan nilai plusnya tampil dalam rangka melengkapi kekurangan yang ada pada konseling konvensional.

\footnotetext{
${ }^{13}$ Agus Akhmadi, “Terapi “Pengguna Obat” dengan Pendekatan Konseling spiritual”, Kajian Materi Diklat Teknis Fungsional Peningkatan Kompetensi Guru Pertama BK MA Surabaya, p. 2.
} 
Analisis yang dilakukan dalam tulisan ini untuk mengetahui dinamika perkembangan regulasi diri santri dari beberapa kegiatan dalam proses konseling Gestalt Berbasis Islam. Intervensi program bimbingan dan konseling Gestalt berbasis Islam dilakukan berdasarkan rancangan yang telah melalui proses uji kelayakan program oleh dosen ahli. Proses penyelenggaraan intervensi dalam penelitian ini terdiri dari enam pertemuan, yaitu pertemuan pertama the beginning phase, pertemuan kedua clearing the ground, pertemuan ketiga dan keempat the existential encounter, pertemuan keempat integration, dan pertemuan keenam ending. Penyelenggaraan intervensi diberikan kepada dua belas orang santri.

Setiap tahapan merupakan proses intervensi yang penulis adopsi dari tahapan yang ada dalam pendekatan Gestalt namun dikolaborasikan dengan nuansa Islami agar konseli tidak jauh dari fitrahnya yakni sebagai hamba Allah. Proses intervensi bimbingan dan konseling Gestalt berbasis Islam penulis rumuskan dalam tiga aspek yakni :
a. Perluasan kesadaran dikaitkan kepada Sang Pencipta (Allah)
b. Kegiatan intervensi didesain dengan nuansa Islami
c. Kesadaran here and now dengan motif ibadah

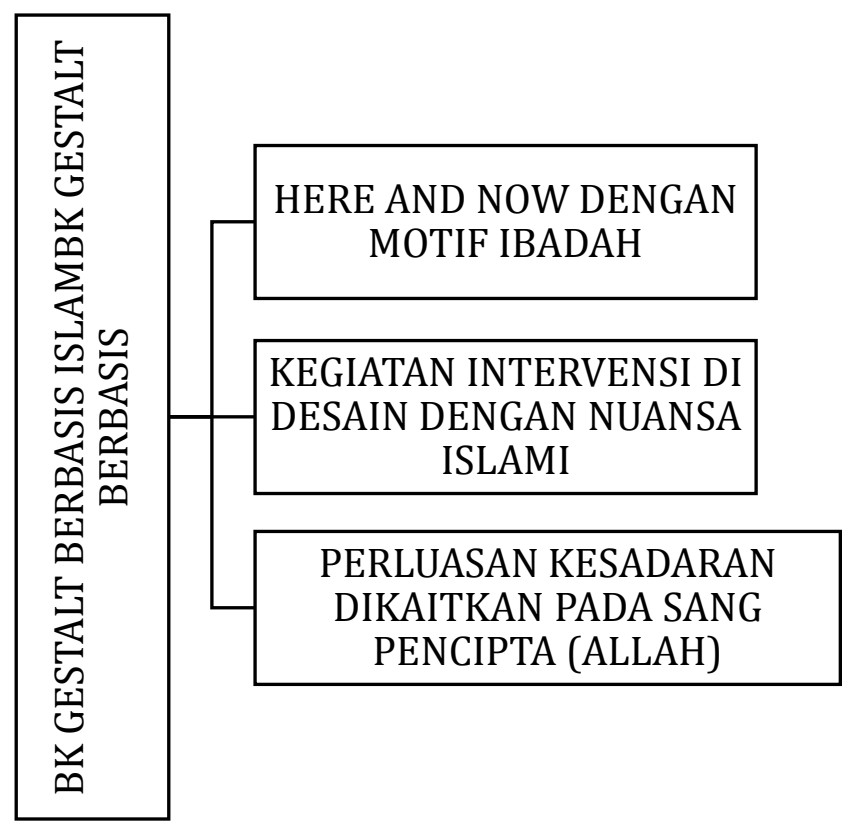

Gambar 1. Gambaran konsep bimbingan dan konseling Gestalt berbasis Islam

Dalam setiap sesi pertemuan, penulis bagi menjadi empat tahapan, yakni tahap pembukaan, tahap peralihan, tahap kegiatan atau tahap inti dan tahap penutup. ${ }^{14}$ Dalam setiap tahapan, setelah intervensi berupa perluasan penyadaran, penulis memberikan sedikit latihan

${ }^{14}$ Sri Narti, Model Bimbingan Kelompok Berbasis Ajaran Islam untuk Meningkatkan Konsep Diri Siswa, (Yogyakarta: Pustaka Belajar, 2014), p. 31. 
dalam meregulasi belajar yang mana latihan tersebut masih ada kaitan dengan upaya perluasan kesadaran dalam tiap tahapan. Pendekatan Gestalt merupakan pendekatan yang lues tidak terpaku pada konsep yang ada dalam teori tertentu. Dalam pendekatan ini, konselor bebas dalam mengembangkan kreativitasnya dalam melakukan intervensi asalkan sejalan dengan prinsip dan konsep yang ada dalam pendekatan Gestalt.

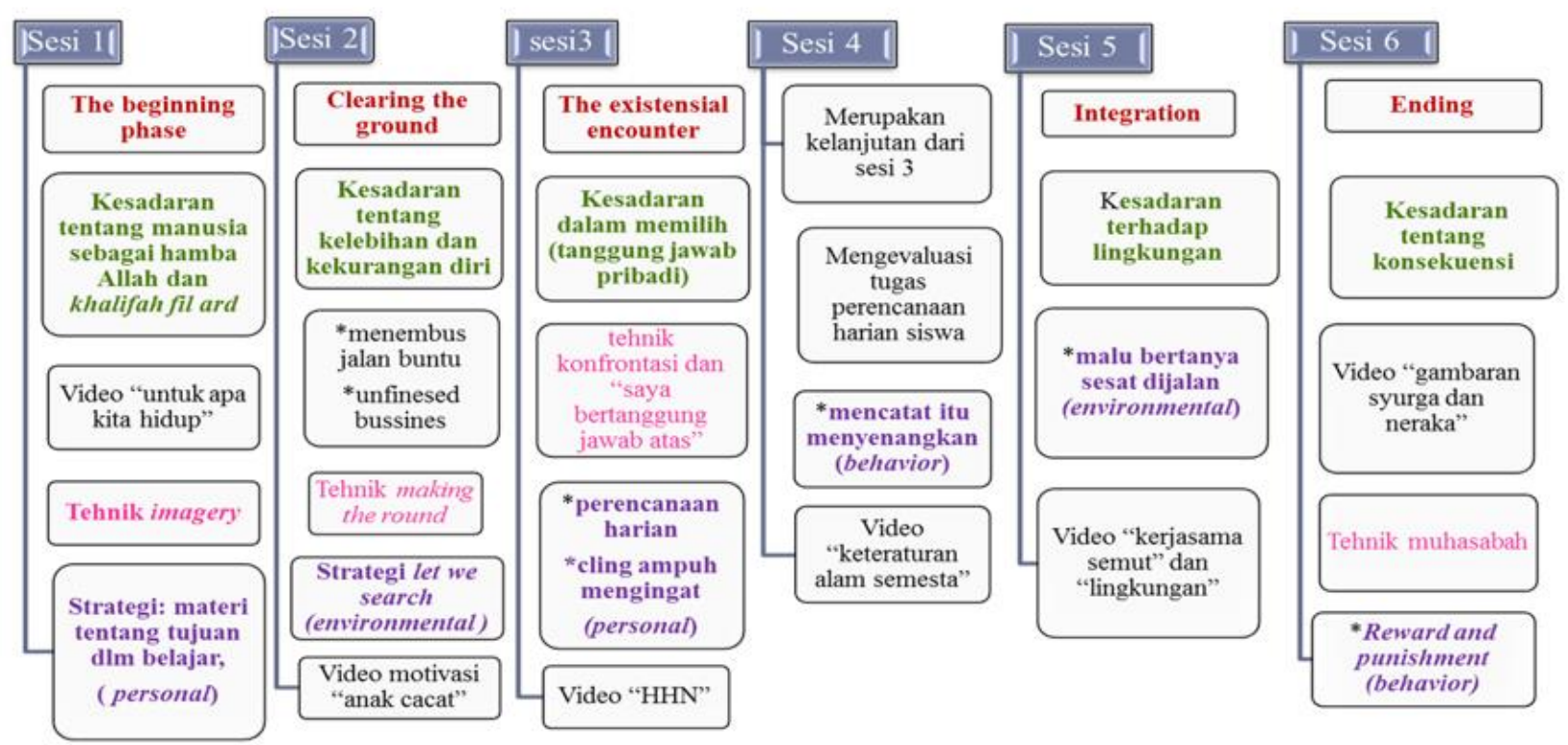

Gambar 2. Proses intervensi bimbingan dan konseling Gestalt berbasis Islam

Keterangan:

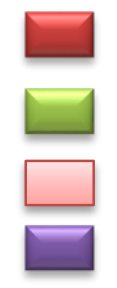

: Tahapan dalam bimbingan dan konseling Gestalt

: Perluasan kesadaran

: Tehnik dalam bimbingan dan konseling Gestalt

: Strategi self regulated learning

\section{E. Intervensi Gestalt Berbasis Islam}

\section{Pertemuan pertama}

Pertemuan pertama ini merupakan tahap awal dari tahapan yang ada dalam pendekatan Gestalt. Tahap pertama (the beginning phase) dari bimbingan dan konseling Gestalt berbasis Islam ini berisi tentang kondisi-kondisi yang esensial bagi bimbingan konseling Gestalt, peneliti menggunakan metode fenomenologi untuk meningkatkan kesadaran dan tanggung jawab pribadi konseli ${ }^{15}$. Adapun kesadaran konseli yang ditingkatkan melalui dalam tahap pertama 
ini adalah kesadaran tentang eksistensi konseli di dunia ini sebagai hamba Allah dengan tugas untuk beribadah dan menjadi khalifah fil ardh yakni sebagai penggantiNya dalam hal mengatur alam dan ekosistem ilahiyah yang rahmatan lil-alamin, menaburkan potensi keselarasan, kemanfaatan musyawarah dan kasih sayang ke seluruh penjuru alam. ${ }^{16}$ Terkait tentang upaya untuk meningkatkan kemampuan self regulated learning konseli, pada sesi pertama ini yang dilakukan peneliti adalah membimbing konseli agar meniatkan segala sesuatu termasuk belajar untuk meraih Ridho Allah (ibadah). Aspek self regulated learning yang hendak ditingkatkan dalam sesi ini adalah personal function konseli.

Kegiatan sesi pertama dilaksanakan pada tanggal 25 Maret 2015 pukul 16.00 WIB. Kegiatan dibuka dengan meminta salah satu konseli untuk melantunkan ayat suci al-Quran, QS. az-Zariyat, (51: 56) dan QS. Fatir, (45:3) dilanjutkan dengan berdoa bersama dan mengecek kehadiran santri. Setelah tahap pembuka dan tahap peralihan, peneliti memberikan pertanyaan kepada konseli tentang apa tujuan hidup mereka didunia ini, hal tersebut peneliti lakukan untuk mengaktifkan otak konseli untuk berfikir secara mendalam. Pertanyaan tersebut merupakan hal terpenting yang harus difikirkan oleh setiap orang Islam sebagai barometer dalam berfikir dan bertindak. Karena seperti yang terjadi dewasa ini banyak sekali orang-orang Islam yang kehilangan jati dirinya, tidak mengetahui apa tujuannya berada di dunia hingga menuhankan harta, tahta dan jabatan.

Jawaban-jawaban yang diutarakan oleh para konseli tentang tujuan penciptaannya dan kehadirannya di dunia, meskipun tidak ada yang salah namun belum ada yang mengena, ada yang menjawab bahwa tujuannya di dunia adalah untuk membahagiakan kedua orang tua, untuk bahagia, untuk menjadi orang yang sukses dan lain sebagainya. Peneliti memberikan self reward berupa hadiah kepada konseli yang jawabannya dianggap cocok. Self reward digunakan untuk memperkuat atau menambah respons yang diinginkan dan berfungsi mempercepat target tingkah laku. ${ }^{17}$ Setelah penulis mengumpulkan jawaban-jawaban yang diutarakan oleh para konseli, penulis mengklarifikasikan jawaban-jawaban tersebut melalui firman Allah dalam QS. az-Zariyat (51: 56) dan QS. Fatir (45: 3).

Klarifikasi merupakan salah satu keterampilan konseling yang dibutuhkan ketika seorang konselor mencoba untuk menyamakan persepsi karena hal yang sering terjadi selama

25.

16 Hamdani Bakran Adz-Dzaky, Konseling \& Psikoterapi Islam, (Yogyakarta: Fajar Pustaka Baru, 2004), p.

17 Mochamad Nursalim, Strategi \& Intervensi Konseling, p. 157. 
proses intervensi adalah apa yang telah didengar dan dipersepsikan konselor belum tentu sama dengan apa yang disampaikan atau dimaksudkan oleh konseli18.

Selanjutnya peneliti mengajak konseli untuk melakukan teknik imagery yang dikolaborasikan dengan muhasabah. Teknik ini secara umum bertujuan untuk memperluas kesadaran subyek dan secara khusus bertujuan untuk merenungi kesalahan-kesalahan yang pernah dilakukan kemudian beristigfar. Istigfar penting kiranya bagi individu yang akan melakukan pembenahan dalam dirinya, karena istigfar berarti kembali pada titik nol, dimana hati bersih dari noda-noda hitam. Ketika hati seseorang telah bersih maka akan mudah untuk memasukkan nilai-nilai positif bagi perkembangan dirinya. Namun jika hati seseorang masih kotor, maka akan sulit dalam memasukkan nilai-nilai positif tersebut. Barang siapa tidak mau segera menuju kepada taubat (istigfar) maka dia berada pada dua bahaya. Bahaya pertama: Kegelapan menjadi bertumpuk-tumpuk dalam hatinya sehingga menjadi kotoran dan menjadi tabiat. Bahaya kedua: Akan menghadap Allah dengan hati yang kotor, padahal tidak akan selamat kecuali orang yang menghadap Allah dengan hati yang bersih. ${ }^{19}$

Dalam teknik imagery ini, penulis mengarahkan konseli untuk menundukkan kepala diiringi musik instrumentalia doa untuk membantu para subyek mencapai kondisi relaksasi. Dalam posisi relax dengan kepala menunduk, konseli diminta untuk menarik nafas dengan mendalam dan mengarahkan agar merasakan setiap tarikan dan hembusan nafas tersebut, setiap menghembuskan nafas peneliti mengarahkan subyek untuk membaca lafadz hamdalah dalam hati secara perlahan sebagai wujud syukur atas segala nikmat yang telah diberikan. Setelah dikira-kira konseli sudah dapat rilex, penulis mengajak konseli untuk membayangkan apa yang telah dilakukan konseli terkait dosa-dosa yang pernah subyek lakukan, dosa karena menyakiti teman, menyakiti kedua orang tua, menyepelekan guru, meninggalkan sholat. Lalu konseli diminta untuk beristigfar didalam hati.

Dalam tahap penutup setelah tehnik imagery selesai, peneliti membagikan lembaran yang berisikan pertanyaan-pertanyaan terkait tentang materi yang telah diberikan pada sesi pertama ini kepada konseli sebagai bahan evaluasi dan pemahaman mendalam bagi subyek, kemudian diakhiri dengan doa kafaratul majlis. Dalam sesi pertama ini, tampak tiga orang dari konseli berjenis kelamin laki-laki yang kurang bersemangat mengikuti kegiatan intervensi. Konseli tersebut terlihat gelisah, sebentar-sebentar melihat kearah jendela dan melamun.

45.

18 Rosita E. Kusmaryani dkk, Modul Keterampilan Konseling, cet, ke II, (Yogyakarta: UNY Press, 2014), p.

19 Syaihk Jamaluddin Al-Qasimi, Buku Putih Ihya 'Ulumuddin Imam Al-Ghazali, (Bekasi: PT. Darul Falah, 2010). p. 554. 


\section{Pertemuan Kedua}

Setelah konseli dapat memahami dirinya sebagai makhluk ciptaan Allah Swt yang dibekali dengan potensi dan diserahi tugas untuk mengabdi kepada Allah Swt diharapkan konseli dapat menerima diri apa adanya, agar mampu mewujudkan sikap positif seperti berperilaku baik kepada sesamanya. ${ }^{20}$ Usaha untuk meluaskan kesadaran diri konseli agar mampu menerima dirinya tersebut dilakukan pada pertemuan kedua dalam kegiatan intervensi bimbingan dan konseling Gestalt berbasis Islam.

Pertemuan kedua merupakan tahap kedua dari tahapan yang ada dalam pendekatan Gestalt (clearing the ground). Dalam tahap ini berlanjut pada strategi-strategi yang lebih spesifik, penulis mendorong dan membangkitkan keberanian konseli untuk memahami dirinya secara utuh baik dari segi kekurangan maupun kelebihannya dan dalam tahap ini juga konselor membantu konseli untuk menembus jalan buntu dan mengatasi urusan yang tidak selesai (unfinished business).

Adapun jalan buntu yang berhasil penulis temukan dalam diri konseli adalah kemalasan, rasa tidak betah dipondok, sedangkan unfinished business yang berhasil penulis temukan pada beberapa konseli adalah permasalahan dengan teman. Kegiatan intervensi pada tahap kedua ini dilaksanakan pada tanggal 26 Maret 2015 pukul 16.00 WIB. Kegiatan dibuka dengan berdoa bersama dan mengecek kehadiran siswa. Untuk memancing kesemangatan konseli, peneliti memberikan ice breaking dengan permainan tepuk finger. Ice breaking dalam bimbingan dan konseling sangat diperlukan untuk membuat gairah belajar menjadi bagus dengan menciptakan suasana santai agar para peserta dapat terhibur dan bersenang hati. ${ }^{21}$ Dalam permainan ini, siapa yang salah antara gerakan dan suara akan diberi hukuman berdiri ditempat dan boleh duduk lagi jika ada teman berikutnya yang salah.

Setelah tahap pembuka dan peralihan selesai, penulis memasuki tahap inti melalui tehnik making the round dengan meminta konseli untuk menulis kelebihan dan kekurangan dirinya pada lembar kertas kolom sebelah kanan yang telah disediakan oleh peneliti, kemudian konseli diminta untuk berkeliling diantara teman-temannya untuk mengisi kolom kanan yang masih kosong terkait kelebihan dan kekurangannya menurut teman yang dia kelilingi.

Setelah selesai, penulis meminta konseli untuk mengumpulkan lembaran tersebut dan membacakan dua buah lembaran tersebut sebagai perwakilan untuk menjelaskan maksud dari

49.

20 Tohirin, Bimbingan dan Konseling di Sekolah dan Madrasah (Jakarta: PT Raja Grafindo Persada, 2012. p.

21 Suwarjo dan Eva Imania Eliasa, 55 Permainan (Games) dalam Bimbingan dan Konseling (Yogyakarta: Paramitra Publishing, 2011), p. 127. 
kegiatan tersebut. Lembaran yang penulis baca pada sesi tersebut adalah atas nama LA yang terkesan masih malu-malu mengungkapkan kelebihan dirinya dan lebih banyak mengungkapkan kekurangannya. Namun tambahan dari teman-temannya mengenai kelebihan dirinya cukup banyak. Hal tersebut mengidentifikasikan bahwa LA adalah seorang yang kurang percaya diri.

Untuk menyegarkan suasana agar konseli tidak bosan, setelah teknik making the rounds selesai, konselor menayangkan video motivasi untuk membangkitkan semangat konseli. Video tersebut menceritakan tentang seorang anak kecil yang cacat namun selalu ceria dan semangat dalam meraih prestasi. Setelah selesai menyaksikan tayangan tersebut, konseli diminta untuk mengungkapkan pendapatnya tentang apa yang dirasakan setelah menyaksikan acara tersebut dan hikmah apa yang dapat diambil dari video tersebut. Kemudian penulis memberikan hadiah bagi konseli yang bisa memberikan argumennya dengan baik. Penulis mengevaluasi semua jawaban dari konseli yang ikut memberikan pendapatnya terkait video yang disaksikan dengan memberikan penjelasan bahwa semua kelebihan yang ada dalam diri konseli yang telah konseli sadari harus disyukuri dan dikembangkan karena Allah akan menambahkan nikmatNya kepada hamba-hambanya yang pandai bersyukur dan akan mengambil nikmat yang ada jika tidak mensyukurinya, karena masih banyak diluar sana orang-orang yang serba kekurangan seperti video yang disaksikan tadi namun memiliki semangat yang tinggi untuk berprestasi. Adapun dalam menyikapi kekurangan yang ada, konselor mengarahkan agar tidak berputus asa dan terus berusaha untuk memperbaiki diri agar menjadi lebih baik.

Setelah menutup kegiatan intervensi, penulis memanggil konseli atas nama HE untuk diberikan intervensi konseling individual. Pemanggilan tersebut berdasarkan lembar masalah yang diungkapkan oleh HE. HE termasuk anak yang aktif dan bersemangat dalam mengikuti kegiatan intervensi. Namun HE mempunyai permasalahan yakni merasa menjadi rebutan kakak-kakak kelas hingga HE merasa banyak dari teman-temannya yang iri. Menurut konselor HE mempunyai rasa percaya diri yang tinggi.

Dalam proses konseling tersebut, konselor tidak menggunakan teknik tertentu dalam pendekatan Gestalt. Konselor hanya menggunakan konsep Gestalt dengan mengajak HE berdiskusi mengenai permasalahan dan apa yang dia rasakan pada saat ini dengan menghindari dari penggunaan kata tanya mengapa. Dan memberi dukungan agar HE tidak terlalu memikirkan semua penilaian negatif tentang dirinya namun tetap berusaha memberi yang terbaik dalam beribadah, belajar dan bermuamalah. 
Dalam sesi ini, masih ada konseli yang kurang begitu memperhatikan dengan baik terutama konseli laki-laki. Diantaranya DK dan RD yang terlihat gelisah dan selalu melihat keluar jendela dan RU yang selalu melamun. Sedangkan subyek perempuan terlihat semangat mengikuti kegiatan intervensi, meskipun masih ada yang hanya diam saja ketika dimintai pendapat.

\section{Pertemuan Ketiga}

Pertemuan ketiga (the existential encounter) dalam sesi ini konselor harus secara kuat memberikan dukungan kepada konseli, memberikan motivasi kepada konseli ketika konseli terlihat berputus asa. Pada tahap ini juga beberapa konseli harus mengambil keputusannya yang besar di dalam hidupnya untuk terus melanjutkan eksplorasi atau puas akan apa yang telah dicapai. ${ }^{22}$ Kesadaran diri konseli yang diluaskan dalam tahap ini adalah kesadaran bahwa setiap pilihan terdapat konsekuensinya.

Setelah penulis mengetahui kekurangan atau hambatan-hambatan dalam diri konseli melalui lembar tugas yang dibagikan dan dianalisis oleh peneliti pada malam harinya, peneliti menantang konseli untuk mengambil sikap untuk berubah atau tetap bertahan dalam permasalahannya melalui tehnik konfrontasi dan "saya bertanggung jawab atas". Teknik ini merupakan perluasan kontinum kesadaran dan dirancang untuk membantu orang-orang agar mengakui dan menerima perasaan-perasaannya alih-alih memproyeksikan perasaanperasaannya itu kepada orang lain. ${ }^{23}$ Adapun hambatan-hambatan potensi pada diri konseli yang penulis dapatkan diantaranya adalah rasa malas, sering ngantuk, tidak disiplin, ceroboh, tidak bisa mengatur waktu.

Kegiatan ini dilaksanakan pada tanggal 27 Maret 2015 pukul 16.00 WIB. Kegiatan dibuka dengan berdoa bersama dan mengecek kehadiran konseli. Ice breaking yang penulis berikan dalam sesi ini berupa hafalan mahfudzot "man jadda wa jada". Setelah membaca doa bersama-sama, penulis mengajak konseli menghafalkan kalimat man jadda wa jada secara berulang-ulang kemudian diikuti oleh seluruh konseli, penulis memberikan hadiah kepada konseli yang pertama kali hafal. Setelah semua konseli menghafalkan mahfudzot tersebut, penulis menjelaskan maksud dari mahfudzot tersebut, bahwa segala kekurangan dan kesulitan yang diungkapkan pada pertemuan kemarin harus dilawan dan diperbaiki, karena Allah tidak akan mengubah suatu kaum kecuali kaum itu sendiri yang mengubahnya. Untuk memperkuat

\footnotetext{
22 Safaria, Terapi, p. 87.

${ }^{23}$ Corey, Teori, p. 137.
} 
penjelasan yang penulis berikan, maka penulis mengajak konseli untuk menyaksikan sebuah video motivasi tentang HHN.

Setelah konseli menyaksikan video tersebut, konseli diminta untuk mengungkapkan hikmah apa yang dapat diambil dari video tersebut. Kemudian penulis menjelaskan bahwa kekurangan-kekurangan yang menghambat konseli untuk berprestasi merupakan suatu tantangan yang harus dihadapi. Pelaksanaan teknik "saya bertanggung jawab atas" dan konfrontasi yang dilakukan oleh peneliti pada sesi ini, dilakukan dengan cara menunjukkan beberapa orang sebagai model untuk diminta mengakui kekurangannya dan bertanggung jawab atas kekurangannya tersebut. Model tersebut diantaranya adalah RD, DK, dan LA. Hambatan dalam diri RD adalah rasa malas, untuk itu RD diminta agar mengakui rasa malas tersebut dan mau bertanggung jawab atas rasa malasnya dalam bertuk verbal "Saya malas dan saya bertanggung jawab atas kemalasan saya".

Kemudian konselor menantang RD untuk tetap malas atau melawan rasa malas tersebut dengan memberi tahukan konsekuensi yang didapat atas pilihannya. Hambatan dalam diri LA adalah suka ngantuk di kelas. Sama seperti RD, UM dan LA juga diminta untuk mengungkapkan hambatannya tersebut dalam bentuk verbal. "saya suka ngantuk jika dikelas, dan saya bertanggung jawab atas ngantuk saya". Kemudian penulis menantang LA untuk melawan rasa ngantuk atau tetap menjadi orang yang ngantukan dikelas dengan menjelaskan dampak positif serta negatif nya. Dan hambatan dalam diri UM adalah tidak dapat mengatur waktu dengan baik. UM diminta untuk mengungkapkan hambatannya tersebut dalam bentuk verbal. "saya tidak dapat mengatur waktu dengan baik dan saya bertanggung jawab untuk itu". Kemudian penulis menantang UM untuk mau merubah sikapnya terhadap waktu atau terus seperti itu dengan menjelaskan segala konsekuensinya. Ketiga subyek tersebut merupakan model untuk meningkatkan kesadaran subyek agar dapat dengan tegas mengambil sikap akan kekurangan yang menghambat potensinya dengan menyertakan ayat suci al-Qur'an untuk menguatkan hal tersebut yakni melalui firman Allah, Q.S, al-Isra (17:36).

Setelah proses penyadaran melalui tehnik konfrontasi dan "saya bertanggung jawab atas", bimbingan yang diberikan dalam tahap ini adalah mengenai perencaan, yang merupakan unsur manajemen yang berfungsi untuk merelisasikan tujuan ${ }^{24}$. Perencanaan disini bertujuan agar konseli dapat mengatur jadwal kesehariannya dengan baik. Bimbingan tersebut dilakukan dengan cara penulis memperlihatkan contoh lembaran kertas perencanaan (planning) 
keseharian penulis mulai dari bangun tidur sampai tidur lagi berikut keterangannya, kemudian meminta subyek untuk melakukan hal yang sama pada selembar kertas yang telah disediakan yakni menulis rencana atau planning untuk besok mulai dari bangun tidur hingga pukul 16.00 WIB secara terperinci kemudian memberikan contengan bintang pada poin rencana yang terlaksana dan contengan silang pada poin yang belum terlaksana. Tugas tersebut dikerjakan di asrama pada malam hari sebelum tidur dan dikumpulkan pada pertemuan berikutnya.

Setelah memberikan penjelasan mengenai tugas yang harus subyek lakukan pada malam hari, peneliti meminta subyek untuk menyimpan lebar tugas tersebut dan melanjutkan intervensi. Intervensi berikutnya yang peneliti berikan adalah berupa bimbingan strategi self regulated learning melalui tema "cling ampuh mengingat". Bimbingan ini hanya berupa penjelasan tentang tips-tips agar dapat menghafal pelajaran dengan baik, diantaranya adalah menghafal dengan mengeluarkan suara dan berulang-ulang seperti yang dicontohkan oleh penulis dalam ice breaking mahfudzot man jadda wa jadda, menghafal ditempat yang sunyi, menghafal sambil bernyanyi, menghafal dengan mengikut sertakan gerakan anggota tubuh, membiasakan menulis dua buah kosa kata berbahasa arab inggris setiap hari pada selembar kertas lalu ditempelkan didinding kamar kemudian menghafalkannya, dan memberi info tentang makanan apa saja yang dapat membantu agar dapat berkonsentrasi.

Kegiatan intervensi ditutup dengan doa kafaratul majlis, kemudian penulis memanggil RU untuk mendapatkan penanganan dalam konseling individual. RU adalah subyek yang pemalu, penulis agak kesulitan mengungkapkan permasalahan yang sedang RU alami. Menurut informasi yang penulis dapatkan dari teman-temannya bahwa RU suka marah-marah, tapi penulis belum berhasil mengungkapkan apa yang menyebabkan RU menjadi anak yang pemarah.

Intonasi suara $\mathrm{RU}$ rendah dan merespon pernyataan yang penulis berikan dengan singkat, oleh karena itu dalam proses konseling individual, penulis menggunakan teknik imagery dan Bekerja dengan Proses-fisik dimana konseli hanya diajak berimajinasi dengan penulis sebagai fasilitator. RU diajak untuk membayangkan dan mensyukuri setiap tarikan nafas yang Allah anugerahkan, jemari yang dapat bergerak gerak dan membayangkan RU disayangi banyak teman kemudian menjadi orang sukses. Tampak RU mengikuti intruksi yang penulis berikan. Pada pertemuan ketiga, konseli mulai menunjukkan ketertarikan terhadap kegiatan intervensi, konseli mulai aktif dalam menjawab pertanyaan maupun mengungkapkan pendapatnya, dan konseli hadir lebih dahulu dari waktu yang ditentukan.

\section{Pertemuan Keempat}


Pertemuan keempat dilaksanakan pada tanggal 28 Maret 2015 pada pukul 16.00 WIB. Pertemuan keempat masih merupakan tahap ketiga dari bimbingan dan konseling Gestalt berbasis Islam. Pada sesi ini, penulis melanjutkan strategi yang berkaitan dengan upaya untuk meningkatan aspek behavior dalam self regulated learning yakni mengevaluasi tugas yang dikerjakan di asrama dan membimbing peneliti tentang cara mencatat yang baik.

Setelah penulis memberikan salam, penulis mengajak konseli membaca doa bersama dan mengecek kehadiran konseli, penulis memberikan ice breaking berupa gerakan senam otak yang dibantu oleh observer, senam otak adalah serangkaian gerak sederhana yang menyenangkan yang digunakan untuk meningkatkan kemampuan belajar dengan mengoptimalkan fungsi otak keseluruhan baik otak kanan maupun otak kiri secara simultan. ${ }^{25}$ Gerakan melalui senam otak ini menurut penulis sangat penting dalam proses pembelajaran. Bergerak dalam cara yang teratur dan halus akan mengaktifkan otak secara penuh dan terintegrasi. ${ }^{26}$ Kemudian peneliti meminta konseli untuk mengumpulkan tugas berupa planning yang harus dilakukan pada hari itu dari bangun tidur sampai pukul 16.00 WIB. Ada beberapa anak yang tidak mengumpulkan tugas yang diberikan dengan alasan lupa, dan hanya satu anak atas nama MA yang dapat mengerjakan tugas sesuai intruksi yang diberikan. Sebagai reward atas hasil kerja tersebut penulis memberikan MA hadiah.

Penulis menjelaskan kembali tentang tugas yang diberikan terkait manajemen waktu dan membimbing konseli agar dapat memilah-milah antara prioritas dan bukan serta berusaha untuk komitmen dalam menjalankan apa yang telah direncanakan dalam tulisan tersebut. Setelah kegiatan bimbingan dalam mengatur waktu selesai, penulis mengajak konseli untuk menyaksikan video tentang keteraturan alam semesta karya harun yahya. Penayangan tersebut bertujuan untuk menguatkan pemahaman (insight) konseli mengapa konseli harus menjadi pribadi yang teratur termasuk teratur dalam memanfaatkan waktu. Penulis menjelaskan bahwa Allah Maha Teratur, menciptakan alam semesta ini secara teratur, karena jika terjadi sedikit saja kecerobohan maka tentunya alam semesta ini akan berantakan dan hancur. Demikian juga jika konseli tidak mampu mengatur dirinya, waktunya, kamarnya, lemari pakaiannya dan lain sebagainya maka tentu akan membuat konseli mengalami kesulitankesulitan hingga menghambat konseli untuk sukses.

Selanjutnya penulis memberikan bimbingan dengan tema "Mencatat itu menyenangkan". Bimbingan ini bertujuan agar konseli dapat membuat catatan yang

26 Jalaluddin Rakhmat, Belajar cerdas belajar berbasiskan Otak (Bandung: MLC, 2005), p. 113. 
terorganisasi dan efektif. Sehingga membantu konseli memperoleh informasi baru tentang bagaimana seni mencatat yang baik, membiasakan diri untuk mencatat dengan baik dan memanfaatkan catatannya dengan baik dalam belajar. Bimbingan ini adalah untuk meningkatkan aspek environmental dalam self regulated learning siswa.

Setelah bimbingan selesai kemudian ditutup dengan doa kafaratul majlis, penulis memanggil dua orang konseli untuk diberikan perlakuan konseling individual yakni DK. DK mendapatkan intervensi konseling individual karena DK terkesan acuh tak acuh dan terlihat kurang berminat mengikuti kegiatan intervensi seperti konseli sering terlambat masuk ruangan dan selalu mengarahkan pandangan ke luar jendela pada saat kegiatan berlangsung seakan-akan merasa jenuh dan ingin segera keluar.

Sikapnya yang cuek dan ogah-ogahan membuat penulis harus memberikan konseling individual dengan pendekatan Gestalt berbasis Islam kepada konseli. Dalam proses konseling, penulis berhasil mengungkap permasalahan yang sekarang dialami oleh DK yakni DK sering diejek oleh teman-temannya karena postur tubuhnya yang kecil hingga sedikit mengganggu kesemangatannya dalam belajar. Teknik yang peneliti berikan dalam proses konseling tersebut adalah teknik self-dialogue yang suportif. Dalam teknik ini, konseli diarahkan untuk merubah dan mengidentifikasi pesan-pesan negatif yang dikatakan kepada dirinya sendiri, dan mendesain ulang pesan-pesan yang lebih positif serta memperkuat sebagai penggantinya. Tujuan dari teknik ini adalah untuk meningkatkan self support konseli yakni agar DK menerima kondisi fisiknya dan tetap bersemangat berprestasi.

Konseling individual yang penulis berikan cukup berhasil memancing ketertarikan DK pada kegiatan intervensi keesokan harinya. Perlahan lahan DK mengurangi pandangannya keluar jendela, lebih memperhatikan materi bimbingan dan konseling dan aktif menjawab pertannyaan yang konselor berikan dalam upaya penyadaran dalam tiap tahapan intervensi. Tentu saja kesempatan tersebut tidak penulis sia-siakan, penulis berupaya memperkuat dan mempertahankan minat DK terhadap kegiatan intervensi dengan memilih subyek untuk menjawab pertanyaan yang konselor berikan kemudian memberikannya hadiah kecil. Pada hari berikutnya, DK terlihat mengambil posisi duduk lebih dekat dengan papan tulis.

\section{Pertemuan Kelima}

Pertemuan kelima dilaksanakan pada tanggal 29 Maret 2015 pukul 16.00 WIB. Pertemuan kelima merupakan tahap keempat (integration). Pada tahap ini konseli mulai memasuki fase pengintegrasian secara menyeluruh dari seluruh diri, konseli juga mulai melakukan proses untuk menciptakan hubungan yang memuaskan dengan orang-orang di 
sekelilingnya maupun dengan lingkungan masyarakat secara luas. ${ }^{27}$ Munculnya regulasi diri pada diri seseorang tidak terlepas dari peran lingkungan. ${ }^{28}$

Kepercayaan pada Allah azza wa jalla menyadarkan manusia akan hakekat relasinya dengan manusia lain, sebab ajaran Islam memerintahkan manusia untuk mencintai sesama makhluk hidup dan menganggap setiap orang adalah saudara ${ }^{29}$. Disamping itu, bersosialisasi dapat membuat otak segar dan baik. Hal tersebut dikarenakan dalam otak kita ada sekelompok sel yang diberi nama sel cermin. Jumlah sel cermin pada manusia jauh lebih banyak dibanding makhluk-makhluk lain. Neuron ini melakukan fungsinya laksana cermin yang membuat bayangan yang sama dengan yang asli. Neuron cermin inilah yang menjadi dasar biologis bagi kecerdasan sosial ${ }^{30}$. Semakin baik sosialisasi seseorang maka semakin baik pula fungsi kerja otaknya.

Dengan mengaitkan antara tahapan kelima dalam Gestalt dan ajaran Islam tentang hidup bersosialisasi maka kesadaran diri yang akan diluaskan dalam tahap ini adalah kesadaran tentang hubungan antara siswa dengan orang-orang di sekelilingnya. Dan untuk meningkatkan self regulated learning konseli, penulis menggunakan strategi bercerita tentang burung pipit agar konseli tidak malu bertanya ketika menemukan kesulitan dalam belajar.

Setelah penulis memberikan salam, penulis mengajak konseli membaca doa bersama dan mengecek kehadiran konseli kemudian penulis membacakan cerita tentang "Pipit merah dan padi". Setelah konseli mendengar cerita dari penulis kemudian konseli diminta untuk menggali hikmah yang terdapat dalam cerita tersebut. Kegiatan tersebut penulis akhiri dengan menjelaskan maksud dari cerita tersebut sambil mengaitkannya dengan Ayat al-Qur'an dalam Q.S. al-Hujurat (49: 13).

Cerita tersebut merupakan usaha untuk meningkatkan aspek environmental dalam self regulated learning konseli, dalam sesi ini konseli digugahkan kesadarannya bahwa sebagai makhluk sosial kita tidak dapat hidup sendiri. Demikian juga dalam proses belajar, melalui cerita tersebut penulis membimbing konseli agar tidak malu-malu bertanya kepada guru atau teman mengenai pelajaran yang tidak dimengerti.

Untuk memperkuat sasaran yang hendak dicapai yakni perluasan kesadaran terhadap lingkungan sekitar, penulis menayangkan video yang penulis ambil di you tube yaitu tentang

\footnotetext{
27 Safaria, Terapi, p. 88.

${ }^{28}$ Lisya Chairani, Psikologi Santri Penghafal al-Qur'an Peranan Regulasi Diri, (Yogyakarta: Pustaka Pelajar, 2010), p. 246.

${ }^{29}$ Kartini Kartono, Hygiene, p. 273.

${ }^{30}$ Mustamir Pedak, Dahsyatkan otak dengan shalat, (Yogyakarta: Mitra Pustaka, 2011), p. 118.
} 
indahnya kebersamaan dan akibat membuang sampah sembarangan. Setelah itu konseli diminta untuk mengambil hikmah apa yang dapat diambil dari video tersebut.

Setelah penulis menutup pertemuan pada sesi ini, penulis memanggil FT untuk diberikan perlakuan berupa konseling individual. FT termasuk anak yang pendiam dan lebih pasif dari YU. Namun dari informasi yang konselor dapatkan, FT merupakan anak yang menduduki peringkat pertama dikelasnya. Hasil dari tugas yang diberikan juga cukup baik. Dan menurut pantauan selama proses kegiatan FT dapat mengikuti kegiatan dengan baik. Hanya saja pada lembaran ungkapan masalah yang konselor buat, FT memiliki masalah dengan teman dekatnya yang akhirnya FT mendapat layanan konseling individual dari konselor.

Dalam kegiatan layanan konseling individual Gestalt, setelah subyek menceritakan permasalahannya saat ini, konselor menerapkan teknik kursi kosong dalam membantu subyek mengatasi permasalahannya. FT kecewa dengan sikap teman dekatnya yang tiba-tiba menjauh darinya. Karena jika tidak dibantu dikhawatirkan akan mengganggu konsentrasi belajar subyek, terlebih FT merupakan remaja awal yang belum begitu kaya akan pengalaman hidup sebagai modal dalam menyikapi permasalahan.

Dalam teknik kursi kosong tersebut, FT diminta untuk mengilustrasikan bahwa kursi kosong yang ada di depannya diduduki oleh teman dekatnya. Kemudian FT diminta untuk mengungkapkan segala uneg-uneg dan kekesalan yang dirasakan kepada kursi kosong tersebut. Tidak berapa lama FT mengungkapkan kekesalan terhadap bangku kosong tersebut, FT meminta izin untuk menangis, dan konselor mengizinkan FT melakukan apa saja yang FT ingin lakukan. Dengan sambil menangis FT mengungkapkan lagi bahwa dia merasa kehilangan, dia ingin agar temannya itu tidak menjauhinya lagi. Setelah FT merasa puas mengungkapkan uneg-uneg yang dirasakan, konselor meminta FT memeluk bangku kosong tersebut dan membayangkan seakan-akan yang dipeluknya adalah teman dekatnya tersebut. Hal tersebut konselor lakukan agar FT tidak dendam dan mau memaafkan temannya.

Setelah teknik bangku kosong selesai, konselor bertanya kepada FT akan apa yang dia rasakan saat ini setelah mengungkapkan semua permasalahannya dan FT mengaku agak plong. Kemudian konselor memberikan FT sedikit tantangan agar FT berani mengungkapkan kekesalannya tersebut kepada temannya itu dengan bahasa yang baik dan lembut. Konselor mengarahkan FT agar tidak memendam setiap permasalahan, karena itu akan mempengaruhi kesehatan fisik FT hingga mengganggu prestasi FT disekolah. Konselor juga mengarahkan jika FT masih tidak berani untuk bicara terus terang akan apa yang FT rasakan, FT cukup mengadahkan kedua tangan kepada sang Kholiq, FT diminta untuk menceritakan segala keluh 
kesah kepada Allah dengan menangis dan mengiba. Karena menyimpan permasalahan dalam hati tanpa secara jujur mau mengungkapkan kepada sesuatu sama halnya dengan menyimpan sebuah penyakit yang suatu saat merusak fungsi organ-organ tubuh.

\section{Pertemuan Keenam}

Pertemuan keenam dilaksanakan pada tanggal 31 Maret 2015. Pertemuan keenam merupakan tahap kelima (ending) dalam pendekatan Gestalt, pada sesi ini konseli siap untuk memulai hidupnya secara mandiri tanpa bimbingan dari konselor. Pada tahap ini konseli sudah memperoleh pemahaman dan penyadaran tentang pikiran, perasaan dan tingkah lakunya, lalu penulis mengantarkan konseli memasuki fase akhir konseling. Pada sesi ini konseli juga sudah menunjukkan gejala-gejala yang mengindikasikan integritas kepribadiannya sebagai individu yang unik. Konseli telah memiliki kepercayaan pada potensinya, menyadari keadaan dirinya pada saat sekarang, sadar dan bertanggung jawab atas, perasaan-perasaannya, dan pikiranpikirannya. ${ }^{31}$ Dalam tahap terakhir ini penulis melakukan tehnik muhasabah melalui firman Allah Q.S Al-Hasyr: 18.

Kegiatan dibuka dengan berdoa bersama-sama dan pengecekan kehadiran konseli, kemudian penulis memberikan ice breaking berupa mahfudzot "man yazro' yahsud" yang artinya barang siapa menanam maka ia akan menuai. Ice breaking ini merupakan permainan menghafal cepat, pertama-tama peneliti melafadzkan mahfuzot tersebut secara terpisah diikuti oleh seluruh subyek secara berulang-ulang kemudian baru melafadzkannya secara keseluruhan dan diikuti oleh seluruh subyek juga secara berulang-ulang. Subyek yang dapat menghafalkan pertama kali mendapatkan hadiah dari penulis. Setelah penulis selesai melakukan ice breaking, penulis meminta subyek untuk menggali apa maksud dari mahfudzot tersebut dan peneliti memberikan hadiah kepada subyek yang dapat menjawab dengan benar maksud dari mahfudzot tersebut. Kemudian peneliti menjelaskan bahwa maksud dari mahfudzot tersebut adalah bahwa kita akan mendapatkan balasan atas apa-apa yang kita lakukan. Jika menanam padi mustahil tumbuh durian, untuk itu jika berbuat baik maka akan mendapatkan kebaikan dan jika berbuat jahat maka yang didapat juga kejahatan.

Setelah kegiatan ice breaking selesai, penulis mengajak konseli untuk menyaksikan video yang telah disiapkan yakni gambaran kehidupan di syurga dan di neraka. Dalam tayangan gambaran neraka tersebut, tampak beberapa konseli perempuan yang menunduk dan memeluk temannya, sambil menyaksikan tayangan tersebut penulis mengarahkan agar konseli 
beristigfar dalam hati sambil mengenang dosa-dosa yang pernah dilakukan seperti dosa karena membentak ayah dan ibu, dosa menyakiti teman, dosa meninggalkan sholat, subyek diarahkan untuk memohon ampun didalam hati dikarenakan begitu dahsyatnya siksaan yang ditampilkan dalam video tersebut bagi mereka yang tidak taat kepada Allah.

Sedangkan ketika tayangan gambaran syurga tampak wajah konseli tersenyum-senyum. Setelah tayangan tersebut, penulis meminta konseli mengungkapkan dalam lembar kertas yang telah disediakan bagaimana perasaan mereka ketika melihat tayangan tersebut, setelah semuanya selesai mengerjakan tugas yang diberikan, peneliti mengambil secara acak lembaran tugas mereka dan membacakannya didepan semua konseli tanpa menyebutkan nama konseli sambil menjelaskan bahwa syurga dan neraka adalah balasan atas apa yang telah kita kerjakan selama didunia, untuk itu konseli disarankan agar berhati hati dalam berkata, melangkah dan bertindak.

Selanjutnya, penulis memberikan bimbingan berupa materi tentang reward and punishment dalam belajar terhadap konseli. Bimbingan tersebut merupakan upaya dalam meningkatkan aspek behavior dalam self regualted learning siswa. Penulis mengarahkan agar konseli memberi hukuman pada diri sendiri ketika gagal dalam mencapai hasil yang ditargetkan atau gagal dalam menyelesaikan tugas yang ditargetkan dengan menghafal lima buah vocab atau mahfudzot, menghafalkan ayat-ayat al-Quran atau al-Hadist, tidak jajan atau bermain bola dan lain sebagainya dan memberi hadiah kepada diri sendiri ketika berhasil mencapai target yang telah ditentukan dalam belajar atau mencapai nilai yang telah ditargetkan dalam mata pelajaran tertentu dengan membeli makanan kesukaan, bermain bola, membaca buku kesukaan, maupun perasaan berupa kepuasan. Intervensi ditutup dengan doa kafaratul majlis dan salam.

\section{F. Penutup}

Konseling gestalt berbasis Islam merupakan penyatuan dua pendekatan yaitu pendekatan Gestalt dan pendekatan Islami. Penyatuan dua pendekatan tersebut merupakan perkawinan antara teori konvensional yang dirumuskan oleh para tokoh Gestalt dengan nilainilai islam yang diambil dari Quran dan Hadist. Konseling Gestalt berbasis islam cukup efektif dalam meningkatkan kemampuan meregulasi diri para santri di pondok pesantren Al-Falaah Pandak Bantul Yogyakarta. Keefektifan tersebut penulis dapatkan dari hasil observasi dari hari pertama treatmen hingga hari terakhir dan wawancara dengan para konseli yakni santri yang terlibat diakhir pertemuan maupun dari hasil evaluasi tertulis. 
Mawa'izh

Jurnal Dakwah dan Pengembangan Sosial Kemanusiaan

Vol. 8, no. 2 (2017), pp. 219-240. 


\section{DAFTAR PUSTAKA}

Corey, Gerald, Teori dan Praktek Konseling dan Psikoterapi, Bandung: PT. Eresco, 2010.

Rosjidan, Panduan Pengajar Pengantar Teori Konseling III, Jakarta: Depdikbud, 1998.

Palmer, Stephen, Konseling dan Psikoterapi, Yogyakarta: Pustaka Belajar, 2011.

Sudrajad, Akhmad, Mengatasi Masalah Siswa Melalui Layanan Konseling Individual, Yogyakarta: Paramitra, 2011.

Akhmadi, Agus, Terapi Pengguna Obat dengan Pendekatan Konseling spiritual. Kajian Materi Diklat Teknis Fungsional Peningkatan Kompetensi Guru Pertama BK MA Surabaya.

Narti, Sri, Model Bimbingan Kelompok Berbasis Ajaran Islam untuk Meningkatkan Konsep Diri Siswa, Yogyakarta: Pustaka Belajar, 2014.

Adz-Dzaky, Hamdani Bakran, Konseling \& Psikoterapi Islam, Yogyakarta: Fajar Pustaka Baru, 2004.

Nursalim, Mochamad, Strategi \& Intervensi Konseling, Jakarta: Akademia Pertama, 2013.

Kusmaryani, Rosita E., dkk. Modul Keterampilan Konseling. Cet. ke II, Yogyakarta: UNY Press, 2014.

Al-Qasimi, Syaikh Jamaluddin, Buku Putih Ihya 'Ulumuddin Imam Al-Ghazali, Bekasi: PT. Darul Falah, 2010.

Tohirin, Bimbingan dan Konseling di Sekolah dan Madrasah, Jakarta: PT Raja Grafindo Persada, 2012.

Suwarjo, \& Eva Imania Eliasa, 55 Permainan (Games) dalam Bimbingan dan Konseling, Yogyakarta: Paramitra Publishing, 2010.

Akram, Ridha, Manajemen Diri Pemuda, Tunggulsari: Media Insani Publishing, 2007.

Rakhmat, Jalaluddin, Belajar Cerdas Belajar Berbasiskan Otak, Bandung: MLC, 2005.

Chairani, Lisya, Psikologi Santri Penghafal al-Qur'an Peranan Regulasi Diri, Yogyakarta: Pustaka Pelajar, 2010.

Mustamir, Pedak, Dahsyatkan otak dengan shalat, Yogyakarta: Mitra Pustaka, 2011. 